\title{
Radiogenic heat production analysis of Fennoscandian Shield and adjacent areas in Sweden
}

\section{Veikkolainen, Toni Henri Kristian}

2019-07

Veikkolainen , T H K, Kukkonen , I T \& Näslund , J-O 2019 , ' Radiogenic heat production analysis of Fennoscandian Shield and adjacent areas in Sweden ', Geophysical Journal International , vol. 218 , no. 1 , pp. 640-654 . https://doi.org/10.1093/gji/ggz186

http://hdl.handle.net/10138/303226

https://doi.org/10.1093/gji/ggz186

cc_by_nc_sa

publishedVersion

Downloaded from Helda, University of Helsinki institutional repository.

This is an electronic reprint of the original article.

This reprint may differ from the original in pagination and typographic detail.

Please cite the original version. 


\title{
Radiogenic heat production analysis of Fennoscandian Shield and adjacent areas in Sweden
}

\author{
Toni Veikkolainen ${ }^{\odot},{ }^{1}$ Ilmo T. Kukkonen ${ }^{1}$ and Jens-Ove Näslund ${ }^{2}$ \\ ${ }^{1}$ Department of Geosciences and Geography, University of Helsinki, P.O. Box 68, FI-00014 Helsinki, Finland. E-mail: toni.veikkolainen@helsinki.fi \\ ${ }^{2}$ Swedish Nuclear Fuel and Waste Management Company, P.O. Box 5864, SE-10240 Stockholm, Sweden
}

Accepted 2019 April 19. Received 2019 April 12; in original form 2018 December 14

\begin{abstract}
SUMMAR Y
In northern Europe, radiogenic heat production of surface rocks has been extensively studied in Finland and Norway alike. This paper presents a heat production analysis of Sweden, based on a rock outcrop data compilation obtained from the Geological Survey of Sweden (SGU). The study area comprises Precambrian Shield, Caledonian and platform cover areas. Altogether 39933 samples with uranium, thorium and potassium concentration $\left(\mathrm{C}_{\mathrm{U}}, \mathrm{C}_{\mathrm{Th}}\right.$ and $\left.\mathrm{C}_{\mathrm{K}}\right)$ and density $(\rho)$ data were available. Heat production (HP) was calculated using raw point data, binning on a regular grid, and averaging by bedrock units in the geological map. Methods based on raw point data and grid-based binning resulted in HP values of $2.5 \pm 4.1$ and $2.5 \pm 5.6$ $\mu \mathrm{W} \mathrm{m}^{-3}$, respectively, while averaging by lithology produced a lower value of $2.4 \pm 1.7$ $\mu \mathrm{W} \mathrm{m}^{-3}$. Limiting the lithology-based averaging to Precambrian bedrockareas resulted in heat production of $2.4 \pm 1.6 \mu \mathrm{W} \mathrm{m}^{-3}$. Due to the small geographic extent of area covered by sediments, this is similar to the Precambrian-only value. Regardless of the calculation method, heat production in Sweden is considerably higher than the corresponding value for Finland. The Swedish platform cover had apparently the lowestheat production $\left(1.0 \pm 1.8 \mu \mathrm{W} \mathrm{m}^{-3}\right)$ of all units but the presence of Precambrian rocks below the sediments means that this value strongly misleads if used to represent the entire upper crust. Svecokarelian (Svecofennian) and Sveconorwegian rocks, which comprised 94.0 per cent of all individual observations, had heat production values of $2.6 \pm 1.8$ and $1.7 \pm 1.4 \mu \mathrm{W} \mathrm{m}^{-3}$, respectively. Although the Swedish data still have large spatial gaps when compared to Finnish data, most bedrock units in Sweden are covered. It is obvious that the higher heat flow of Sweden compared to that of Finland is caused by near-surface (i.e. upper crustal) heat production, and crustal differentiation in Sweden is also larger.
\end{abstract}

Key words: Composition and structure of the continental crust; Heat flow; Europe; Spatial analysis; Cratons; Crustal structure.

\section{INTRODUCTION}

Radiogenic heat production is one of the key geothermal parameters of the lithosphere. It has been studied with the help of airborne surveys, and laboratory measurements of samples from glacial till or from the underlying basement. Airborne surveys of radioactivity were initiated in Sweden in late 1960s due to the interest towards uranium prospecting, yet thorium and potassium concentrations have been also determined to estimate heat production in general. By now the majority of the Swedish land area has been surveyed using radiation measurements from a fixed wing aircraft with 30-60 m altitude and 200-800 m line spacing (Kock \& Samuelsson 2011). The largest areas currently devoid of airborne $\mathrm{U}, \mathrm{Th}$ and $\mathrm{K}$ data are located in the Caledonides, as seen in the online map provided by the Geological Survey of Sweden (SGU; https://apps.sgu.se/kartvisare/). On the other hand, data from till measurements have been published in Geochemical Atlas of Sweden (Andersson et al. 2014), with U, Th and $\mathrm{K}$ concentration maps included therein.

\section{DATA AND NORDIC PERSPECTIVE}

In Nordic countries, the interest towards mapping heat production using outcrop data has been manifested by surveys of Norwegian (Slagstad 2008) and Finnish (Veikkolainen \& Kukkonen 2019) bedrock outcrop data. No study based on Swedish outcrop data has been undertaken yet, despite the presence of an abundant lithogeochemical database at SGU. It incorporates measurements from prominent lithologies of the country, allowing the calculation of heat production (HP). For this purpose, we used the equation of 
Rybach (1973):

$\mathrm{HP}=\rho\left(9.52 \mathrm{C}_{\mathrm{U}}+2.56 \mathrm{C}_{\mathrm{Th}}+3.48 \mathrm{C}_{\mathrm{K}}\right) \times 10^{-5}\left[\mu \mathrm{W} \mathrm{m}^{-3}\right]$,

where $\rho$ is the rock density $\left[\mathrm{kg} \mathrm{m}^{-3}\right]$ and $\mathrm{C}_{\mathrm{U}}, \mathrm{C}_{\mathrm{Th}}$ and $\mathrm{C}_{\mathrm{K}}$ are concentrations of $U$ [ppm], Th $[\mathrm{ppm}]$ and $\mathrm{K}$ [ per cent], respectively. These radiogenic isotopes account for $c a .98$ per cent of heat production in rocks. As many as 40306 samples had this information, compared to the number of 6465 samples in the Finnish lithogeochemical database (Rasilainen et al. 2007). However, the Finnish data are relatively evenly distributed throughout the country, despite the stratified sampling procedure which favours areas with smallscale lithological variation. The distribution of Swedish data is much more uneven, with some areas entirely devoid of data. Also in Norway, the situation is closer to that of Sweden than to that of Finland (Slagstad 2008). Various interpolation methods, such as radial basis functions (RBF; Fornberg et al. 2002), can be applied to deal with the problem of uneven data. In Finland, RBF interpolation has provided a mean heat production of $1.4 \pm 1.2 \mu \mathrm{W} \mathrm{m}^{-3}$, compared to the value of $1.3 \pm 1.2 \mu \mathrm{W} \mathrm{m}^{-3}$ calculated using the arithmetic average and standard deviation from point data (Veikkolainen \& Kukkonen 2019). On the other hand, Slagstad (2008) averaged Norwegian heat production data in ArcGIS software by using actual geological unit sizes as weighting factors, instead of applying any interpolation. This procedure is also applied in our paper.

Because Swedish bedrock has been adequately documented with lithogeochemical codes, we used a separate compilation of 10963 density measurements in addition to 40306 determinations of $\mathrm{C}_{\mathrm{U}}$, $\mathrm{C}_{\mathrm{Th}}$ and $\mathrm{C}_{\mathrm{K}}$ data. The data compilations partly overlapped, and therefore a number of density values could be directly associated with $\mathrm{C}_{\mathrm{U}}, \mathrm{C}_{\mathrm{Th}}$ and $\mathrm{C}_{\mathrm{K}}$ data from same localities, yet not necessarily from same samples. To combine density data with radiogenic element concentration data, we used sample codes from both data compilations and $X-Y$ coordinates in SWEREF99 TM system with $15^{\circ} 00^{\prime} \mathrm{E}$ as a central meridian and 0.9996 as a scale factor. Both $X$ and $Y$ were in metres, not in kilometers, and to avoid negative $\mathrm{X}$ values, $500000 \mathrm{~m}$ had been added to each $X$ coordinate value. The precision of coordinate data was $1 \mathrm{~m}$ both in the case of density data and element concentration data, yet in some cases, different rock types appeared at same localities. A typical case is a Precambrian granitic basement cut by narrow dykes, such as those in the 1526-1497 Ma Ragunda rapakivi formation close to Caledonides (Piper 1979; Persson 1999) and those of the coeval Rödö complex (Moakhar \& Elming 2000; Andersson \& Förster 2003) on the east coast. Mainly because of duplicate measurements of element concentrations from same locations and even from same samples, as many as 23260 (57.7 per cent) of all $\mathrm{C}_{\mathrm{U}}, \mathrm{C}_{\mathrm{Th}}$ and $\mathrm{C}_{\mathrm{K}}$ data could be attributed to actual density measurements. For the rest of the radiogenic element data, we calculated the mean density for their respective source rocks and applied that value in eq. (1), in place of the actual $\rho$ value from the locality. Some rare source rocks, such as metasyenitoids and peridotites, were represented by $\mathrm{C}_{\mathrm{U}}, \mathrm{C}_{\mathrm{Th}}$ and $\mathrm{C}_{\mathrm{K}}$ data but not by $\rho$ data and were left out from further investigation because densities of rocks vary from 2519 to $3510 \mathrm{~kg} \mathrm{~m}^{-3}$ and therefore the presence of $\rho$ data was required to ensure consistency in methodology. As many as 39933 of 40306 (99.0 per cent) element concentrations could be assigned either to actual $\rho$ data from same locations, or to mean $\rho$ data from similar lithology, regardless of location. We used this data set as a basis in our subsequent analyses. For unaveraged heat production values calculated using eq. (1), see Appendix A.

Before visualizing heat production by lithological polygons in ArcGIS as previously done in the case of Norway and Finland
(Slagstad 2008; Veikkolainen \& Kukkonen 2019), we decided to average multiple data from same locations for the purpose of visualizing point data by their coordinates. The number of unique $X-Y$ coordinate pairs with $\mathrm{C}_{\mathrm{U}}, \mathrm{C}_{\mathrm{Th}}, \mathrm{C}_{\mathrm{K}}$ and $\rho$ data turned out to be 15208 . Before any further analyses, we averaged values of heat production parameters $\left(\mathrm{C}_{\mathrm{U}}, \mathrm{C}_{\mathrm{Th}}, \mathrm{C}_{\mathrm{K}}\right.$ and $\left.\rho\right)$ for each site using a simple arithmetic mean (Table 1), converted rectangular coordinates to geographic ones and plotted data in maps (Figs 1-3). While studying $\mathrm{Th} / \mathrm{U}$ ratio remains important for understanding metamorphism (Hyvönen et al. 2005), our Swedish data has no consistent information about the metamorphic grade of rocks, and also, the ratio calculation can easily become biased when either $\mathrm{C}_{\mathrm{Th}}$ or $\mathrm{C}_{\mathrm{U}}$ or both are very close to detection threshold. Values below the threshold were treated as zero in the original Swedish data and their use in $\mathrm{Th} / \mathrm{U}$ ratio calculation results would result in zero, or division error. Therefore we did not produce a $\mathrm{Th} / \mathrm{U}$ map because it would have not included all data present in individual concentration maps. Also, we were unable to produce box plots of $\mathrm{Th} / \mathrm{U}$ ratio and heat production by metamorphic grade in the way done for Finnish data. In Finland, high $\mathrm{Th} / \mathrm{U}$ ratios are common in highly metamorphosed granitoids (Veikkolainen \& Kukkonen 2019), but the correlation between heat production and metamorphic gradeis weak in Finland and also globally (Hasterok et al. 2018).

The Swedish sampling site with the largest amount of raw data, that is 19 entries from gneiss granites and other granitoids, had SWEREF99 TM coordinates 467082,6322974 and was situated in the $1713+2 /-3$ Ma Alvesta pluton of the Trans-Scandinavian Igneous Belt (TIB; Johansson 1990; Högdahl et al. 2004). However, the spatial density of data in the immediate vicinity of this point is small. Parts of the 2.44-1.96 Ga Svecofennian area close to Stockholm and parts of the 1.14-0.90 Ga Sveconorwegian area close to the west coast (Balling 2013; Sadeghi et al. 2013) have been sampled more densely, and so are the more northerly rapakivi granite areas (Persson 1999; Andersson \& Förster 2003) too. Unfortunately, the Caledonian orogeny, which represents a unique tectonothermal age in Sweden, is very poorly represented in terms of data density, and the northern Swedish Caledonides are entirely devoid of data.

In the Swedish data, differences between heat production values calculated using density data from sampling location, and heat production values calculated using mean densities from the respective rocks were generally small. If density data were unavailable, an estimated average density from same rocks could be reasonably used. Applying the value of $2.65 \mathrm{~kg} \mathrm{~m}^{-3}$ (Lindén et al. 1983) as mean upper crustal rock density for Finland and Sweden as a whole in the heat flow-heat production study of Näslund et al. (2005) is therefore not an oversimplification. In our compilation, the heat production determined from mean density of each lithology was on average just $0.02 \mu \mathrm{W} \mathrm{m}^{-3}$ smaller than that determined from the sample density. The distribution of these differences had a standard deviation of $0.33 \mu \mathrm{W} \mathrm{m}{ }^{-3}$. The largest negative differences were $-2.83,-1.68,-1.29,-1.11$ and $-0.81 \mu \mathrm{W} \mathrm{m}^{-3}$, and the largest positive differences were $1.30,0.98,0.84,0.83$ and $0.60 \mu \mathrm{W} \mathrm{m}^{-3}$ in the raw data. Except for a brief comparison of measured rock density and heat production, we decided to use mean densities of lithologies in analyses of this paper.

In our spatial analysis, we applied a grid with lower and upper limits of 292 500-907500 m in $X$ direction (easting) and with 6152 500-7 622500 $\mathrm{m}$ in $Y$ direction (northing). The dimensions of an individual cell were 5000 by $5000 \mathrm{~m}$ and therefore the total number of cells was $126 \times 298=37548$. To concentrate on areas with an adequate number of data points, we binned our unstructured data to this grid. After assigning each $X-Y$ coordinate pair in the 
Table 1. Heat production (HP) constituents in raw data before and after averaging by sampling site coordinates.

\begin{tabular}{|c|c|c|c|c|}
\hline & $\begin{array}{c}\text { Before averaging } \\
\quad(N=39933)\end{array}$ & $\begin{array}{l}\text { After averaging } \\
(N=15208)\end{array}$ & $\begin{array}{l}\text { After averaging and } \\
\text { grid binning (loose; } \\
\quad N=9954)\end{array}$ & $\begin{array}{l}\text { After averaging and } \\
\text { grid binning (strict; } \\
\qquad N=5421 \text { ) }\end{array}$ \\
\hline $\begin{array}{l}\text { Mean } C_{U} \pm S D \\
{[p p m]}\end{array}$ & $4.61 \pm 14.65$ & $4.60 \pm 20.84$ & $4.65 \pm 15.94$ & $4.63 \pm 14.89$ \\
\hline $\begin{array}{l}\text { Mean } \mathrm{C}_{\mathrm{Th}} \pm \mathrm{SD} \\
{[\mathrm{ppm}]}\end{array}$ & $15.03 \pm 16.62$ & $14.65 \pm 14.79$ & $15.07 \pm 16.70$ & $14.92 \pm 16.10$ \\
\hline Mean $C_{K} \pm$ SD [\%] & $3.26 \pm 1.40$ & $3.24 \pm 1.35$ & $3.26 \pm 1.40$ & $3.27 \pm 1.39$ \\
\hline $\begin{array}{l}\text { Mean } \rho \pm \mathrm{SD} \\
{\left[\mathrm{kg} \mathrm{m}^{-3}\right]}\end{array}$ & $2698.8 \pm 88.6$ & $2702.4 \pm 89.8$ & $2699.0 \pm 88.8$ & $2698.6 \pm 88.4$ \\
\hline $\begin{array}{l}\text { Mean HP } \pm \text { SD } \\
{\left[\mu W \mathbf{m}^{-3}\right]}\end{array}$ & $2.50 \pm 4.12$ & $2.47 \pm 5.53$ & $2.52 \pm 4.43$ & $2.50 \pm 4.17$ \\
\hline
\end{tabular}

data to a certain grid cell, we produced a set of grid cells appropriate for subsequent analysis (data mask) and left the remaining cells without attention. In the loose binning, not only cells with actual data points were included in the mask, but also nine surrounding cells in each case. This meant that the maximum possible distance from a data point to the farthest edge of the mapped area was $2 \times \sqrt{ } 2 \times 5000 \mathrm{~m}=14140 \mathrm{~m}$. The total number of grid cells where heat production parameters was to be calculated in this scheme was 9954. The density of sampling sites was $15208 / 9954=1.5$ per grid cell, that is one site per $16.4 \mathrm{~km}^{2}$.

In the situation where all cells with no data were left out of analysis, the number of cells accepted for heat production analysis was only 5421 . In this strict binning, the density of sampling sites was $15208 / 5421=2.8$ per grid cell, that is one site per $8.9 \mathrm{~km}^{2}$. This value is much higher than the density of one site per $52 \mathrm{~km}^{2}$ of data (Rasilainen et al. 2007) in the analysis of the Finnish heat production (Veikkolainen \& Kukkonen 2019), yet the Finnish data covered the all major geological units of the country in a much more consistent way without significant spatial gaps. We tabulated Swedish heat production constraints in the case of loose binning and in the case of strict binning as well (Table 1). In loose binning, 40.5 per cent (380200 $\left.\mathrm{km}^{2}\right)$ of grid cells had values for $\rho, \mathrm{C}_{\mathrm{U}}, \mathrm{C}_{\mathrm{Th}}$ and $\mathrm{C}_{\mathrm{K}}$, and in strict binning, 14.4 per cent of cells $\left(135525 \mathrm{~km}^{2}\right)$ had the same information. For the visual comparison of data coverage of these binning options and resulting heat production values, the reader is referred to Appendix B. In both cases, binning does not take any actual geological constraints into account, but it is only used to calculate averages within fixed cells.

ur The Swedish $\rho, \mathbf{C}_{\mathrm{U}}, \mathrm{C}_{\mathrm{Th}}$ and $\mathrm{C}_{\mathrm{K}}$ data was based on commonly applied methods, that is weighing samples in air and water, Inductively Coupled Plasma Mass Spectrometry (ICP-MS), and X-ray fluorescence spectrometry (XRF). We did not analyse the relation of heat production to various properties such as seismic $P$-wave velocity or concentrations of silica and ferric oxide in the way done by Veikkolainen \& Kukkonen (2019), who failed to find any systematic correlations of that kind in Finland. Detailed Swedish geochemical surveys have been carried out in areas like the Bergslagen mining district in northern Svealand (Kumpulainen et al. 1996) and Kristineberg deposit in the Skellefteå group (Hannington et al. 2003). Wilson \& Åkerblom (1982) determined eight areas of granites with anomalously high heat production; (A1) southern Norrbotten, (A2) northern Västerbotten, (B) Hotagen, (C) Bergslagen, (D) Bohus, (E) Gothenburg, (F) Götemar and (G) Blekinge. In particular, the Halen granite of Götemar area turned out to have extremely high $\mathrm{C}_{\mathrm{U}}(27 \pm 5 \mathrm{ppm})$ and $\mathrm{C}_{\mathrm{Th}}(80 \pm 6 \mathrm{ppm})$ values, while its $\mathrm{C}_{\mathrm{K}}$ is also high (5.0 \pm 0.1 per cent), but not exceptional. Landström et al. (1979) also determined high values for the Halen granite; 4.4 per cent for $\mathrm{C}_{\mathrm{K}}, 23.7 \mathrm{ppm}$ for $\mathrm{C}_{\mathrm{U}}$ and $61.1 \mathrm{ppm}$ for $\mathrm{C}_{\mathrm{Th}}$, leading to a heat production of $10.7 \mu \mathrm{W} \mathrm{m}{ }^{-3}$. The term 'granite' is sometimes used as a generalization of rocks with silica content over 65 per cent (McLaren \& Powell 2014), but in this paper, we refer to granites sensu stricto rather than sensu lato, in line with classification in the original Swedish lithogeochemical data.

For analysing heat production by actual lithotectonic areas, we used the 1: 1000000 bedrock map of Sweden (https://apps.sgu.se/ka rtvisare/kartvisare-berggrund-1-miljon.html), available in ArcGIS shapefile format (shp). The map incorporated 147 lithotectonic areas, yet not all of them were represented by heat production data. The total number of polygons within these areas was as large as 8800 , although 6994 of them were devoid of heat production data points. The remaining 1806 polygons, however, covered an area of $355838 \mathrm{~km}^{2}$, compared to the area of $249276 \mathrm{~km}^{2}$ of empty polygons. The all 8800 polygons together comprised an area much larger than the Swedish land area, because a couple of of them extended to the sea. In particular, size of polygon, which included Gotland, was $30825.4 \mathrm{~km}^{2}$, almost ten times the actual land area of the island $\left(3183.7 \mathrm{~km}^{2}\right)$. To avoid bias caused by seafloor in area-weighted heat production estimate, we reshaped this area, and therefore the platform cover shrinked from 34933.5 to $7291.8 \mathrm{~km}^{2}$. From Phanerozoic areas of Öland and Scania, no data were available but neither did heat production polygons cover those areas. In Proterozoic (post-1.8 Ga) magmatic and sedimentary provinces, one column obviously included sea area. We removed this part and recalculated the polygon area, shrinking it from 3566.5 to 809.6 $\mathrm{km}^{2}$. The reduction in area is small and the operation was mainly done to improve the appearance of the map. The total area of Proterozoic (post-1.8 Ga) magmatic and sedimentary provinces also changed from 23057.8 to $20300.9 \mathrm{~km}^{2}$. With these two changes taken into account, the total area of units with heat production data decreased from 355837.8 to $328196.1 \mathrm{~km}^{2}$. For a general view of Swedish geological units and subunits, the reader is referred to Fig. 4.

Statistics of heat production parameters were calculated within each polygon, and areas of particular interest were taken into a more detailed investigation. Polygons with the largest number of data are listed in Table 2. All polygons belonged to six main tectonic units: Blekinge-Bornholm orogen, Caledonides, Platform cover, Proterozoic (post-1.8 Ga) magmatic and sedimentary provinces, Svecokarelian orogen and Sveconorwegian orogen. All polygons had distinct area identification codes (IDs). 
Bedrock density $\left[\mathrm{kg} / \mathrm{m}^{3}\right]$

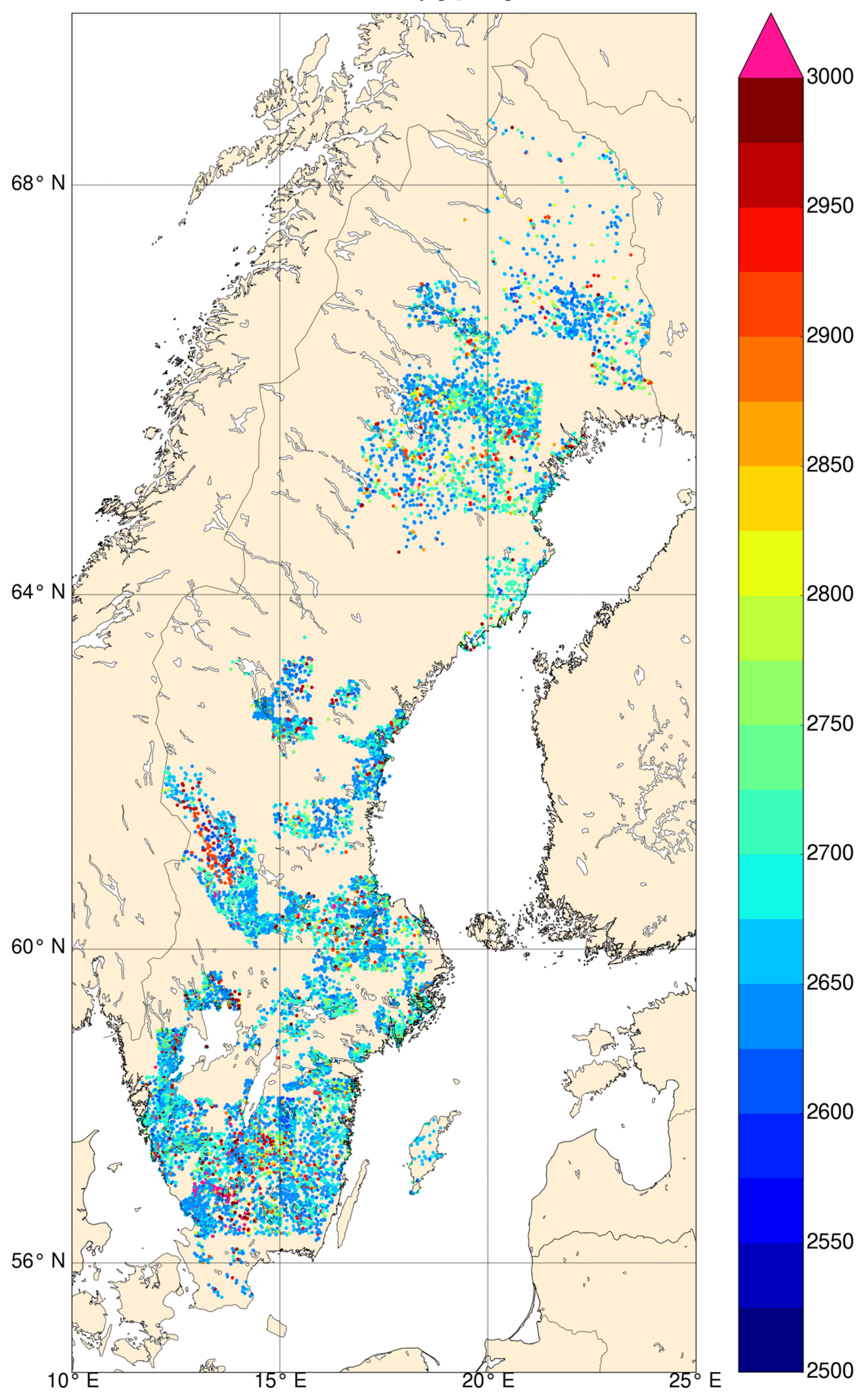

Figure 1. Bedrock density by individual data sites $(N=15208)$. For sites with more than one initial value, site-level average has been used. Data $\odot$ SGU. 

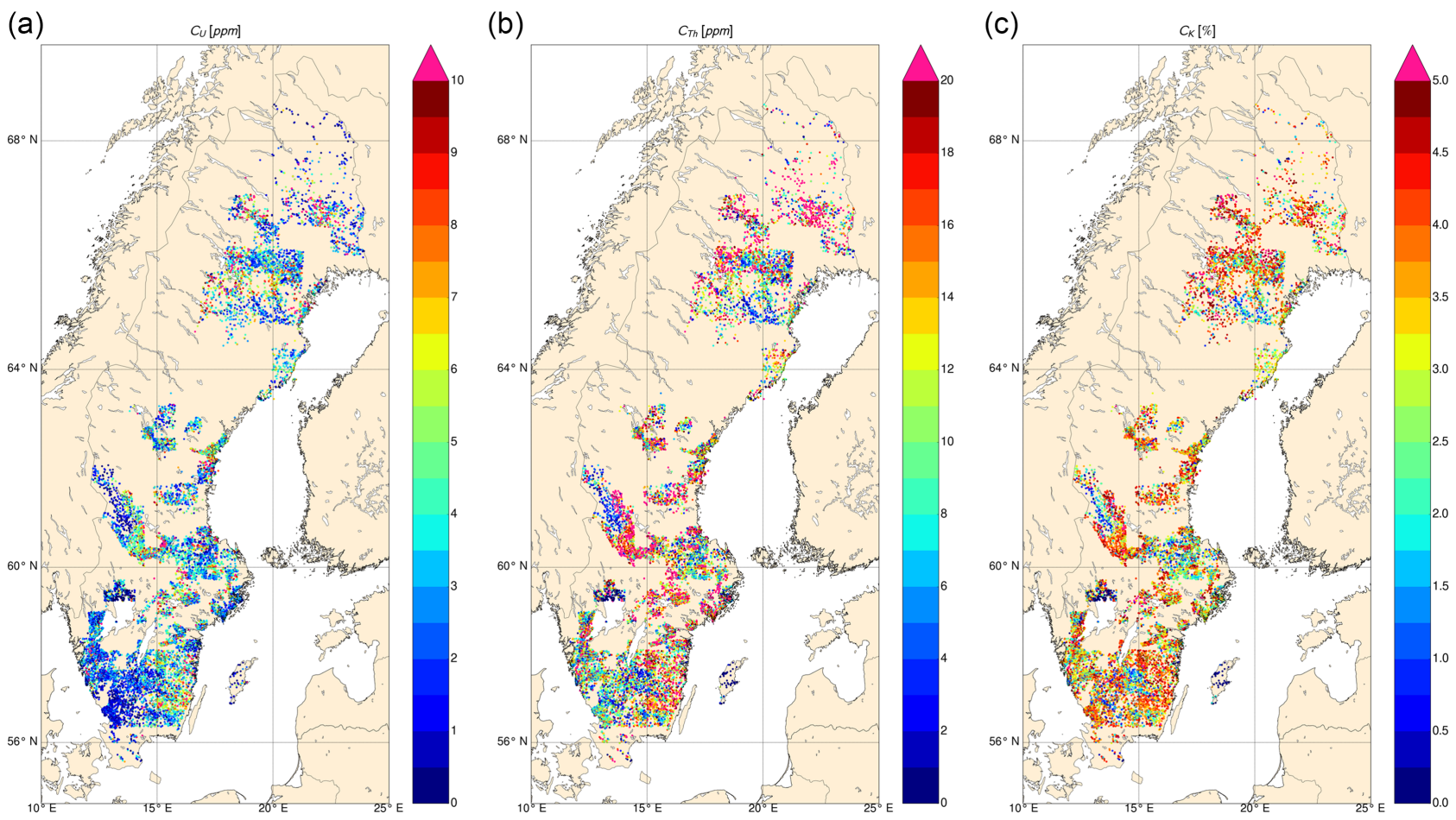

Figure 2. Concentration of (a) uranium (b) thorium and (c) potassium by individual data sites ( $N=15$ 208). For sites with more than one initial value, site-level average has been used. Data ${ }^{\circ}$ SGU.

\section{RESULTS}

Analysing the Swedish data by main tectonic units (Table 3) reveals several interesting features. The highest area-weighted mean heat production occurs in the Caledonides, yet this is most likely a sampling bias. Caledonide polygons with at least one data point cover an area of $12166 \mathrm{~km}^{2}$, yet the spatial distribution of the 134 data points is highly uneven, with the northern Caledonides being almost devoid of data. A polygon with a size of $7676 \mathrm{~km}^{2}$ in the southern part of the Swedish Caledonides features a high mean heat production $4.03 \pm 3.47 \mu \mathrm{W} \mathrm{m}^{-3}$, yet only nine measurements have been used to determine this value. Close to the Norwegian border, a small polygon with the size of $132 \mathrm{~km}^{2}$ only is represented by 30 data points with the mean heat production of $1.18 \pm 0.21$ $\mu \mathrm{W} \mathrm{m}{ }^{-3}$. However, to the southwest observations are more abundant in an area dominated by Jotnian sandstones. Right east of the Caledonides, a polygon consisting of granites, granodiorites, syenitoids, quartz monzodiorites and metamorphic equivalents in the Bothnia-Skellefteå unit has just 2 samples in an area of $6936 \mathrm{~km}^{2}$. As many as 37620 of 39918 observations (94.2 per cent) and 1661 out of 1806 polygons (92.0 per cent) belong to Svecokarelian and Sveconorwegian tectonic units, which had heat production values of $2.6 \pm 1.8$ and $1.7 \pm 1.4 \mu \mathrm{W} \mathrm{m}^{-3}$, both higher than estimated average in the upper 12-14 km layer of the crust globally, ca. 1.6 $\mu \mathrm{W} \mathrm{m}^{-3}$ (Huang et al. 2013; Rudnick \& Gao 2014).

In the Swedish bedrock map, main units are divided into subunitswhich consist of distinct rock types. However, Proterozoic (post-1.8 Ga) magmatic and sedimentary provinces, platform cover, Caledonides and Blekinge-Bornholm orogen have only one subunit. On the other hand, Sveconorwegian bedrock consists of four subunits (Idefjorden terrane, upper unit of eastern segment, middle unit of eastern segment, lower unit of eastern segment) and all Svecokarelian bedrock to six subunits (Bergslagen, Bothnia-Skellefteå, Ljusdal, Norrbotten, Småland and Överkalix; Fig. 4, Appendix C).
The Blekinge-Bornholm orogen is also the southernmost exposed part of the Fennoscandian Shield, located south of the SmålandBlekinge deformation zone (SBDZ), the. Most rocks in the area crystallized at $1.75-1.77 \mathrm{Ga}$, yet thermal overprinting occurred at 1.45-1.40 Ga (Johansson et al. 2005). The area-weighted mean heat production in Blekinge rocks is $2.36 \pm 1.08 \mu \mathrm{W} \mathrm{m}^{-3}$, slightly lower than the Svecokarelian average of $2.63 \pm 1.78 \mu \mathrm{W} \mathrm{m}^{-3}$. The 1.83-1.82 Ga Oskarshamn-Jönköping belt (Mansfeld et al. 2005), which consists of calc-alkaline intrusions, volcanic rocks and coarse-grained clastic metasediments, has lower heat production compared to the surrounding TIB rocks. To the north, the 1.8 Ga Småland subunit of Svecokarelian orogen has an area of 23974 $\mathrm{km}^{2}$ and an area-weighted mean heat production of $2.55 \pm 1.40$ $\mu \mathrm{W} \mathrm{m}{ }^{-3}$. In the more northerly $58658 \mathrm{~km}^{2}$ Bergslagen subunit, the corresponding heat production value is $2.72 \pm 1.90 \mu \mathrm{W} \mathrm{m}^{-3}$. Especially in central-western Bergslagen, 1.85-1.75 Ga granites and pegmatites with heat production over $4 \mu \mathrm{W} \mathrm{m}{ }^{-3}$ are common. Bergslagen is bordered by the Ljusdal subunit in the north, characterized by $1.96-1.84 \mathrm{Ga}$ rocks with a dominance of $1.87-1.84$ Ga metamorphic granitoids. This part of Svecokarelian Sweden has an area-weighted value of $2.41 \pm 1.29 \mu \mathrm{W} \mathrm{m}^{-3}$. The larger Bothnia-Skellefteå subunit has a greater diversity in rock types, which is also reflected in the larger standard deviation of heat production $\left(2.48 \pm 1.64 \mu \mathrm{W} \mathrm{m}^{-3}\right)$. The corresponding value for the more northerly Norrbotten subunit is $3.13 \pm 2.52 \mu \mathrm{W} \mathrm{m}{ }^{-3}$, and for the Överkalix subunit, $2.24 \pm 1.58 \mu \mathrm{W} \mathrm{m}^{-3}$. In the Sveconorwegian part of Sweden, the western Idefjorden terrane had an area-weighted mean heat production of $1.95 \pm 1.71 \mu \mathrm{W} \mathrm{m}^{-3}$. Put together, the three other more easterly Sveconorwegian subunits feature a slightly lower value, $1.65 \pm 1.22 \mu \mathrm{W} \mathrm{m}^{-3}$. The southern part of the Eastern Segment, where heat production is lowest, very high $\mathrm{Th} / \mathrm{U}$ ratios are common. In Sveconorwegian area, only the eastern part represents reworked crust of the TIB, opposite to the western part which is 
Heat production $\left[\mu \mathrm{W} / \mathrm{m}^{3}\right]$

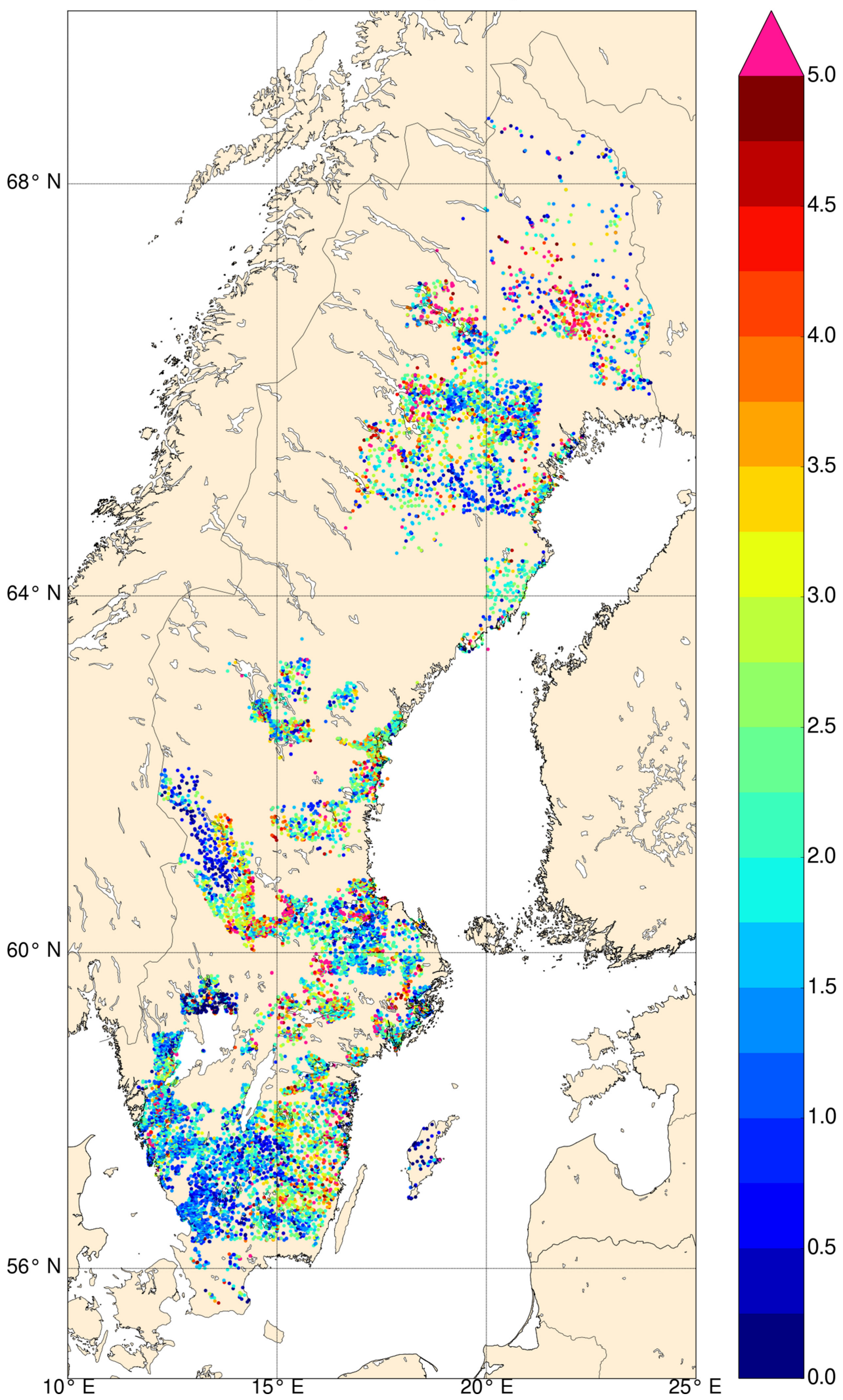

Figure 3. Heat production by individual data sites $(N=15208)$. For sites with more than one initial value, site-level average has been used. Data $\odot$ SGU. 


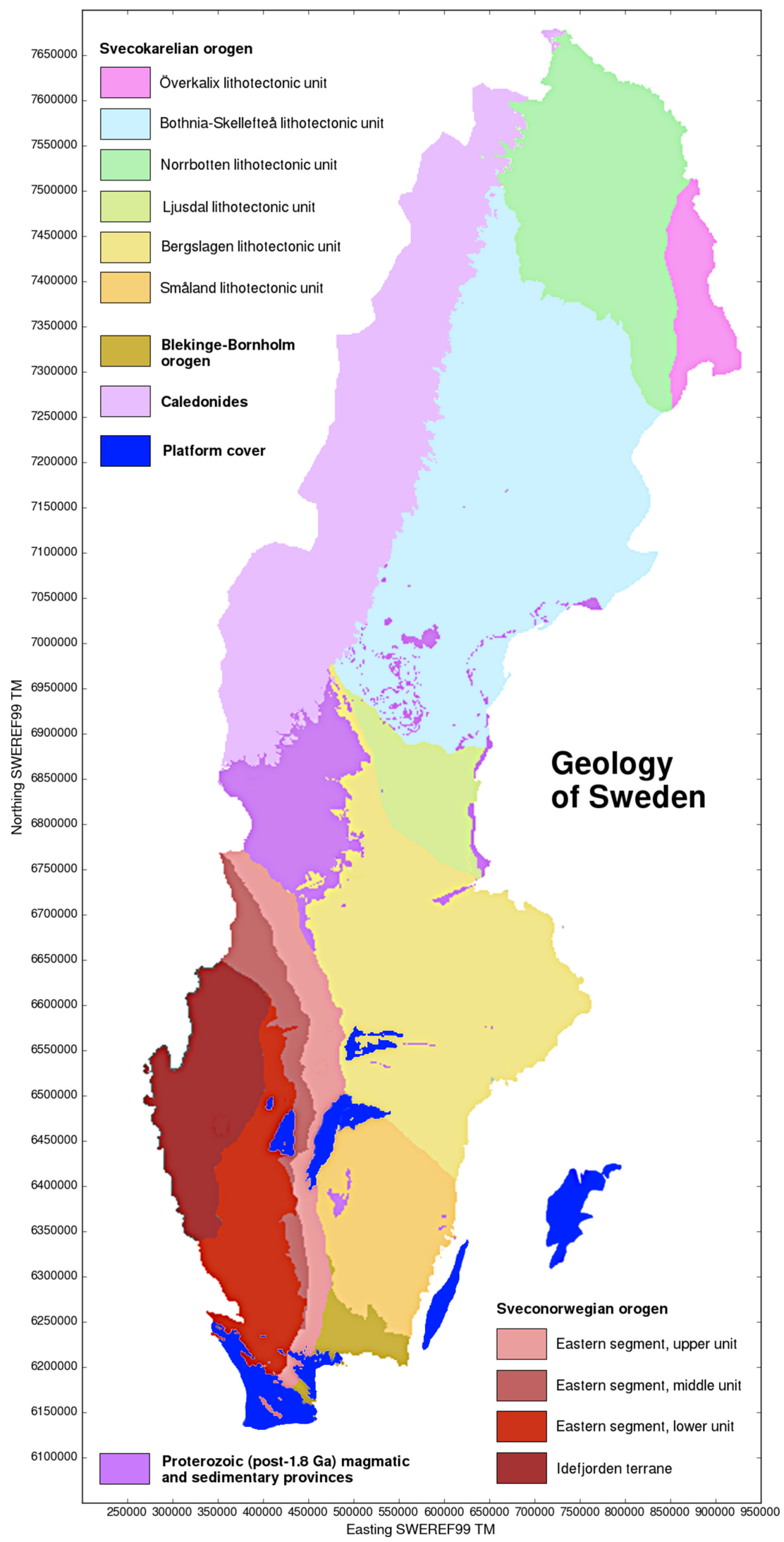

Figure 4. Swedish geological units (bold font) and subunits (normal font). All Swedish land area is shown, including polygons with no heat production data. 
Table 2. Swedish map areas with the greatest number of heat production data points.

\begin{tabular}{|c|c|c|c|c|}
\hline Area ID & Rock type & $N$ & Area $\left[\mathrm{km}^{2}\right]$ & $\begin{array}{l}\text { Mean } \mathrm{HP} \pm \mathrm{SD} \\
\quad\left[\mu \mathrm{W} \mathrm{m}^{-3}\right]\end{array}$ \\
\hline 1057 & $\begin{array}{l}\text { Granitoid and subordinate syenitoid ( } c a \text {. } \\
1.91-1.87 \mathrm{Ga} \text { ), metamorphic; Svecokarelian } \\
\text { orogen; Bergslagen lithotectonic unit }\end{array}$ & 3159 & 24142 & $2.31 \pm 2.21$ \\
\hline 847 & $\begin{array}{l}\text { Granite, granodiorite, syenitoid, quartz } \\
\text { monzodiorite and metamorphic equivalents } \\
(1.8 \mathrm{Ga}) \text {; Svecokarelian orogen; Småland } \\
\text { lithotectonic unit }\end{array}$ & 2605 & 17975 & $2.63 \pm 1.50$ \\
\hline 7838 & $\begin{array}{l}\text { Granitoid (1.6-1.5 Ga), metamorphic; } \\
\text { Sveconorwegian orogen; Idefjorden terrane }\end{array}$ & 2200 & 13296 & $1.92 \pm 2.03$ \\
\hline 1135 & $\begin{array}{l}\text { Metagreywacke, mica schist, graphite- and/or } \\
\text { sulphide-bearing schist, paragneiss, migmatite, } \\
\text { quartzite, amphibolite (ca. 1.96-1.87 Ga); } \\
\text { Svecokarelian orogen; Bothnia-Skellefteå } \\
\text { lithotectonic unit }\end{array}$ & 1760 & 29687 & $2.53 \pm 2.22$ \\
\hline 6815 & $\begin{array}{l}\text { Granitoid to syenitoid migmatitic gneiss ( } 1.7 \\
\text { Ga); Sveconorwegian orogen; Eastern } \\
\text { Segment, lower unit }\end{array}$ & 1175 & 8874 & $1.35 \pm 0.91$ \\
\hline
\end{tabular}

Area IDs are from the geological map of Sweden, available in ArcGIS shapefile format from the Geological Survey of Sweden.

Table 3. Heat production by main Swedish tectonic units.

\begin{tabular}{|c|c|c|c|c|c|}
\hline Main tectonic unit & Subunits & $N_{\mathrm{p}}$ & $N_{\mathrm{d}}$ & Area $\left[\mathrm{km}^{2}\right]$ & $\begin{array}{l}\text { Mean HP } \\
{\left[\mu \mathrm{W} \mathrm{m}^{-3}\right]}\end{array}$ \\
\hline $\begin{array}{l}\text { Blekinge-Bornholm } \\
\text { orogen }\end{array}$ & $\begin{array}{l}\text { Blekinge-Bornholm } \\
\text { orogen }\end{array}$ & 14 & 226 & 3180.6 & $2.36 \pm 1.08$ \\
\hline Caledonides & Caledonides & 13 & 134 & 12166.4 & $2.89 \pm 2.38$ \\
\hline Platform cover* & $\begin{array}{l}\text { Platformal sedimentary } \\
\text { cover rocks }\end{array}$ & 16 & 201 & 7291.8 & $0.95 \pm 1.80$ \\
\hline Proterozoic (post-1.8 & Proterozoic (post-1.8 & 102 & 1737 & 20300.9 & $1.88 \pm 0.81$ \\
\hline $\begin{array}{l}\text { Ga) magmatic and } \\
\text { sedimentary provinces }\end{array}$ & $\begin{array}{l}\text { Ga) magmatic and } \\
\text { sedimentary provinces }\end{array}$ & & & & \\
\hline $\begin{array}{l}\text { Svecokarelian } \\
\text { (Svecofennian) orogen }\end{array}$ & $\begin{array}{l}\text { Bergslagen lithotectonic } \\
\text { unit, Bothnia-Skellefteå } \\
\text { lithotectonic unit, } \\
\text { Ljusdal lithotectonic } \\
\text { unit, Norrbotten } \\
\text { lithotectonic unit, } \\
\text { Småland lithotectonic } \\
\text { unit, Överkalix } \\
\text { lithotectonic unit }\end{array}$ & 1364 & 28172 & 216243.0 & $2.63 \pm 1.78$ \\
\hline Sveconorwegian orogen & $\begin{array}{l}\text { Eastern segment, lower } \\
\text { unit; Eastern segment, } \\
\text { middle unit; Eastern } \\
\text { segment, upper unit, } \\
\text { Idefjorden terrane }\end{array}$ & 297 & 9448 & 66256.5 & $1.74 \pm 1.37$ \\
\hline All main units & & 1806 & 39918 & 325439.2 & $2.37 \pm 1.65$ \\
\hline $\begin{array}{l}\text { Precambrian main } \\
\text { units }^{* *}\end{array}$ & & 1777 & 39583 & 305981.0 & $2.38 \pm 1.62$ \\
\hline
\end{tabular}

Subunits are also listed. $N_{\mathrm{p}}=$ number of polygons, $N_{\mathrm{d}}=$ number of data points, Area = total area of tectonic unit, Mean $\mathrm{HP} \pm \mathrm{SD}=$ mean heat production and standard deviation calculated as a weighted averages, using polygon area as a weighting factor.

*The majority of the platform area consists of seafloor rather than land. The most important land areas are Gotland and parts of Scania, but heat production data are available from Gotland only.

** Precambrian-only data exclude Caledonides and platform cover. For a map of these units and subunits, see Fig. 4, yet note that polygons without heat production data are also shown therein.

younger (Bingen et al. 2008; Roberts et al. 2013; Slagstad et al. 2018).

The largest Swedish areas with high heat production turned out to be concentrated in the Norrbotten subunit, representing 1.88 $1.75 \mathrm{Ga}$ tectonothermal ages on the geological map. There are 121 polygons with a mean heat production of $5.0 \mu \mathrm{W} \mathrm{m} \mathrm{m}^{-3}$ or more, with a total area of $13039 \mathrm{~km}^{2}$, visible in fuchsia color in Fig. 5. The vast majority of these polygons represented Svecokarelian tectonothermal age, with a total area of $12540 \mathrm{~km}^{2}$. They were present in all six Svecokarelian subunits, with the exception of Ljusdal. The rest 


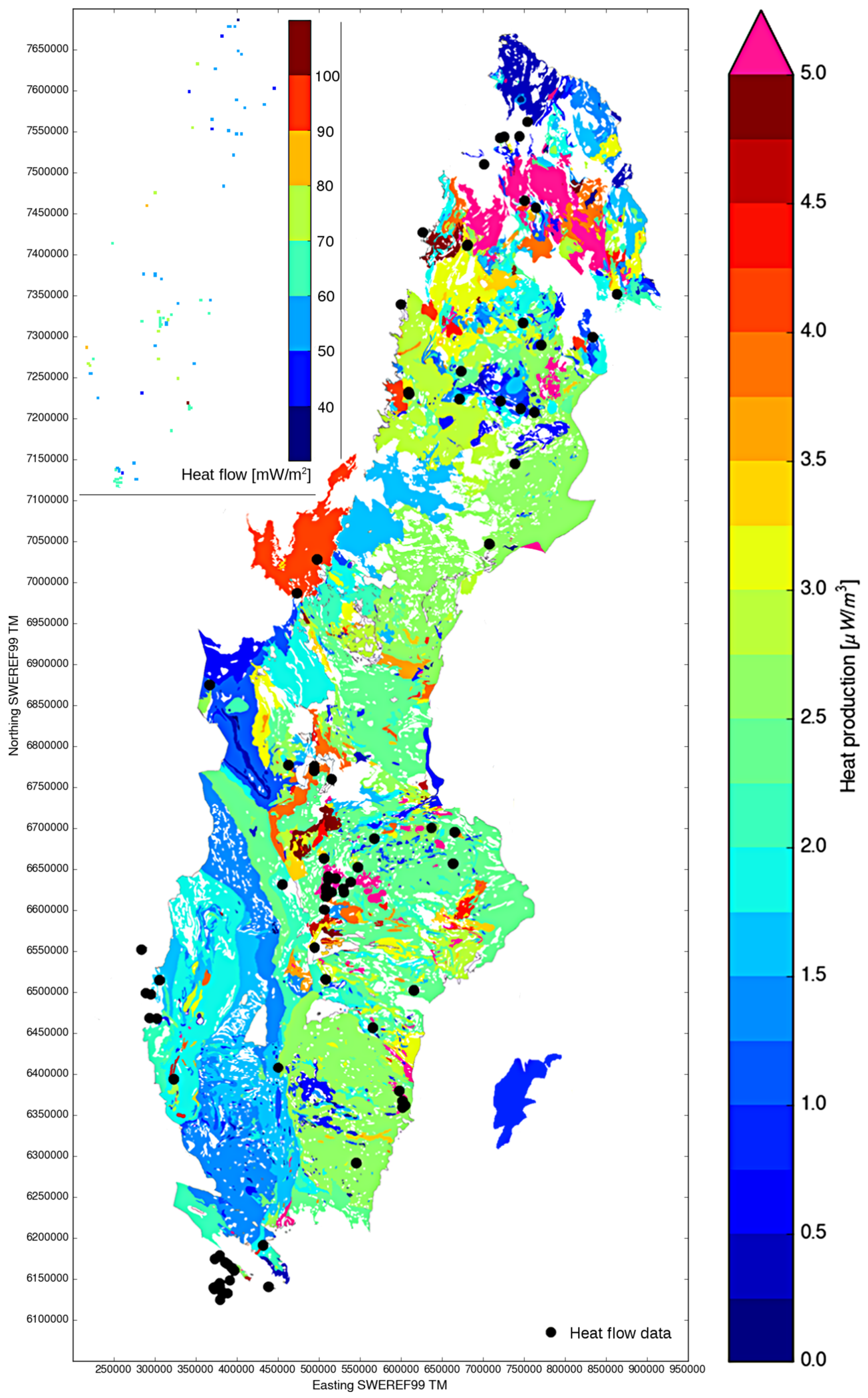

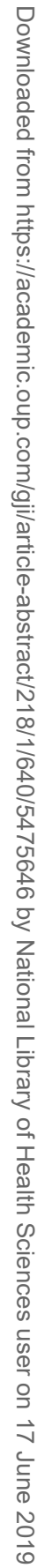

Figure 5. Heat production by geological unit polygons in Sweden. Heat flow sites $(N=86)$ are shown with dots. The subplot indicates heat flow values binned using the $10 \mathrm{~km}$ grid. For a more detailed description of areas with high heat production (over $5 \mu \mathrm{W} \mathrm{m}{ }^{-3}$ ), see Appendix C, and for a more detailed description on heat flow data, Appendix D. Data (C) SGU. 
were Sveconorwegian $\left(193 \mathrm{~km}^{2}\right)$, or belonged to other post-1.8 Ga igneous and sedimentary provinces $\left(204 \mathrm{~km}^{2}\right)$, platformal sedimentary cover rocks $\left(11 \mathrm{~km}^{2}\right)$, or Blekinge-Bornholm orogen $\left(91 \mathrm{~km}^{2}\right)$. In southern Sweden, the western area composed of Sveconorwegian rocks is distinct with its low heat production, while the eastern part composedof Svecokarelian and Blekinge-Bornholm orogen rocks has higher values. Most polygons with high heat production, over $5 \mu \mathrm{W} \mathrm{m}^{-3}$, are represented by only a few samples and are also small in area. The majority of them are also Svecokarelian, falling within a narrow age range (Appendix C). An investigation of polygons with heat production of $5-10 \mu \mathrm{W} \mathrm{m}^{-3}$ reveals a $1.85-1.75 \mathrm{Ga}$ granite-pegmatite area in Norrbotten, with an area of $1242.8 \mathrm{~km}^{2}$ and heat production of $5.3 \pm 4.7 \mu \mathrm{W} \mathrm{m}^{-3}$ determined from 257 samples. A nearby area, also representing 1.85-1.75 Ga granitepegmatites, has an area of $4040.3 \mathrm{~km}^{2}$ and heat production of $6.1 \pm 5.3 \mu \mathrm{W} \mathrm{m}^{-3}$ determined from 213 samples. In Norrbotten, the third major area with high heat production $\left(5.0 \pm 3.9 \mu \mathrm{W} \mathrm{m}^{-3}\right)$ is represented by 133 samples on an area of $1481.1 \mathrm{~km}^{2}$. On the other hand, an extremely low heat production of $0.5 \pm 0.3 \mu \mathrm{W} \mathrm{m}^{-3}$, is apparent in the 3.20-2.65 Ga rocks of the far northern Sweden, comparable to Finnish Archean areas (Veikkolainen \& Kukkonen 2019). Actually, the only Swedish sedimentary area with a substantial number of heat production determinations, namely Gotland, has a higher heat production than the northernmost part of the country (Table 1).

The choice between two binning options did not appear to affect heat production much. The value of $2.52 \pm 4.43 \mu \mathrm{W} \mathrm{m}^{-3}$ obtained from loose binning after site-level averaging is essentially the same as the value of $2.50 \pm 4.17 \mu \mathrm{W} \mathrm{m}^{-3}$ obtained from strict binning after site-level averaging. In an analysis of Finnish and Swedish earthquake data, Veikkolainen et al. (2017) concluded that the apparently nonexistent link between terrestrial heat flow and seismic cutoff depth requires that any major heat flow variations must result from shallow lying (i.e. upper crust) heat producing units. The Swedish heat production data, despite not covering the entire country, covers most major Swedish lithologies. Therefore sampling bias is unlikely to explain the higher heat production in Sweden compared to that in Finland. However, calculation of heat production from mapped Swedish tectonic units using weighted averages of unit sizes results in a slightly smaller value $\left(2.37 \pm 1.65 \mu \mathrm{W} \mathrm{m}^{-3}\right)$ compared to grid-based result. After polygon modification described in Section 2, this value does not involve seafloor which would bias the result, yet the presence of Precambrian rocks below the Phanerozoic cover means that results from Gotland only represent the surface (Sopher et al. 2016). Leaving the Phanerozoic parts, that is Caledonides and platform cover, out of analysis leads to a unit-weighted heat production of $2.38 \pm 1.61 \mu \mathrm{W} \mathrm{m}{ }^{-3}$. This is also close to the value obtained from grid-based binning and obviously a more realistic value for the upper crustal heat production in Sweden, even though the thickness of the upper crust is poorly constrained globally and varies within a large range of 2-16 km globally (Hasterok \& Chapman 2011).

In the Finnish data (Veikkolainen \& Kukkonen 2019), different interpolation options greatly affected the slope of linear heat flow-heat production (Q-A) plots, but estimated mean heat flow was subject to minor changes only. Although the uneven and impractical distribution of heat flow data in Sweden does not allow a reliable determination of Q-A plots except for a very limited data from granitoids with high heat production (Pinet \& Jaupart 1987), it is obvious from point data and interpolated maps (Slagstad et al. 2009; Veikkolainen et al. 2017) that heat flow in Sweden is larger than that in Finland. The geotherm representing high surface heat flow in Fennoscandia, namely $60 \mathrm{~mW} \mathrm{~m}^{-2}$ was related to the upper crustal heat production constraint of $2.1 \mu \mathrm{W} \mathrm{m}^{-3}$ in Veikkolainen et al. (2017). Given the uncertainties inherent in determination of one-dimensional geotherms, this values is surprisingly close to our average Swedish heat production rates which are in the range of 2.1$2.5 \mu \mathrm{W} \mathrm{m}{ }^{-3}$. Unlike data in this study, the Swedish part of the heat flow data compilation of Veikkolainen et al. (2017) does not include the heat flow determination made for the proposed site for a spent nuclear fuel repository at Forsmark (Sundberg et al. 2009), nor for the previously suggested alternative site of Laxemar $\left(63.3 \mathrm{~mW} \mathrm{~m}^{-2}\right.$, also in Sundberg et al. 2009). Neither does it incorporate the recent heat flow determination from the $c a .1820 \mathrm{~m}$ deep borehole in Lake Vättern (47.0 $\mathrm{mW} \mathrm{m}^{-2}$, Sundberg et al. 2016), important because it is located far from other boreholes in southern Sweden. For Laxemar, a mean heat flow of $61.0 \mathrm{~mW} \mathrm{~m}^{-2}$ of Sundberg et al. (2016) and the previous result (Hurter \& Hänel 2002) was used as the data point value in the calculation of mean Swedish heat flow. No palaeoclimatic corrections were available for Vättern, but the depth behaviour of heat flow in the diorite section of the borehole makes it reasonable to assume that the heat flow constraint $\left(47 \mathrm{~mW} \mathrm{~m}^{-2}\right)$ from the deepest measured section of the hole $(1700-1800 \mathrm{~m})$ is closest to a value undisturbed by long-term climate variations. We used this constraint as a reasonable approximation of palaeoclimatically corrected heat flow. Put together, Swedish heat flow values have a mean $\mathrm{Q}=62.8 \pm 12.4 \mathrm{~mW} \mathrm{~m}^{-2}$ calculated from palaeoclimatically corrected point data and $\mathrm{Q}=52.0 \pm 11.4 \mathrm{~mW} \mathrm{~m}^{-2}$ from uncorrected point data. From the Finnish data gathered by Veikkolainen et al. (2017), the corresponding values are $Q=42.1 \pm 11.3$ and $37.3 \pm 11.0 \mathrm{~mW} \mathrm{~m}^{-2}$. Palaeoclimatic disturbance is the most obvious source of uncertainty in heat flow determinations of northern Europe (Čermak et al. 1993; Slagstad et al. 2009; Majorowicz \& Wybraniec 2010) and therefore palaeoclimatically corrected values should be preferred over uncorrected ones despite the great uncertainty on glacial history and basal thermal conditions of ice sheets (Näslund et al. 2005). Detailed descriptions of application of ground surface temperature models are available only for a few boreholes, such as Forsmark and Laxemar (Sundberg et al. 2009), yet these are too shallow to record the entire depth range of palaeoclimatic disturbance (Kukkonen \& Jõeleht 2003).

In Fig. 5, heat flow sites are shown on a map with heat production calculated for each polygon and also in a subplot with a colour bar. Polygons without heat production constraints are left blank. It is obvious that consistent comparison of heat flow and heat production is not as straightforward as it is in Finland, where all lithological units have been mapped adequately in a geochemical database (Rasilainen et al. 2007). Apparently, in far southern sediment-covered area of Sweden the lack of heat production data is most serious. South of Trans-European Suture Zone, heat flow has been determined on 19 sites (Hurter \& Hänel 2002). All of these are outside polygons with heat production data available. Even if heat production constraints from surface rocks of this area are available, these may give misleading results for comparison with heat flow, because lithosphere is not sedimentary by volume. It has been estimated that globally only 4 per cent of lithospheric volume is sedimentary although sediments cover 73 per cent of the Earth's surface (Wilkinson et al. 2009)).

Spatial gaps in heat production data are apparent in the south, but also in northernmost Sweden, which has been the most important target to exploration geophysics and geology. For example, heat flow in Kiruna is $51 \mathrm{~mW} \mathrm{~m}^{-2}$ as determined from five boreholes (Parasnis 1982), but no heat production values for this well-known 
mining area are available. On the other hand, as many as three heat flow determinations $\left(69,69\right.$ and $\left.76 \mathrm{~mW} \mathrm{~m}^{-2}\right)$ are available from amphibolite facies granite of Malingsbo (Malmqvist et al. 1983) in central Sweden, known for its high heat production $(9.6 \pm 1.9$ $\mu \mathrm{W} \mathrm{m}^{-3}$ as determined from the unit polygon). Also, 10 measurements are available at distances less than $20 \mathrm{~km}$ from the border of the same granite area, yet on unit polygons with heat production of just $2.3-2.4 \mu \mathrm{W} \mathrm{m}^{-3}$. Exceptionally high heat flow of $108.7 \mathrm{~mW} \mathrm{~m}^{-2}$ has been determined in 1.87-1.91 Ga quartzite-dominated lithology in Solstad mine (Eriksson \& Malmqvist 1979 compared to the value of $62.6 \mathrm{~mW} \mathrm{~m}^{-2}$ from Kråkemåla (Hurter \& Hänel 2002) only $13 \mathrm{~km}$ apart. A little farther (19 and $20 \mathrm{~km}$ ) from Solstad, the Avro and Laxemar heat flow values $\left(61.5\right.$ and $\left.63.3 \mathrm{~mW} \mathrm{~m}^{-2}\right)$ resemble those of Kråkemala although Kråkemala hole is situated on a unit polygon with mean heat production of $6.1 \pm 0.1 \mu \mathrm{W} \mathrm{m}{ }^{-3}$, only slightly smaller that of the unit polygon of Solstad, $7.3 \pm 9.2 \mu \mathrm{W} \mathrm{m}^{-3}$. The granitoid area where Avro and Laxemar holes are located, is by its large extent one of the most prominent ones in the geological map of Sweden and has a heat production of $2.6 \pm 1.5 \mu \mathrm{W} \mathrm{m}^{-3}$ (Table 2).

In the Sveconorwegian Idefjorden granite-pegmatite area which extends past Norwegian border, four Swedish heat flow sites are not located on any polygon with heat production data available. Unfortunately, these also include the borehole drilled to 4-km-thick granite body in Bohus, of particular importance due to its very high heat flow of $76 \mathrm{~mW} \mathrm{~m}^{-2}$ (Landström et al. 1980). Heat production values obtained from Norwegian Idefjorden units (Slagstad 2008), exceed the Sveconorwegian average obtained from our Swedish data analysis $\left(1.74 \pm 1.37 \mu \mathrm{W} \mathrm{m}^{-3}\right)$. The average obtained from 385 determinations from the Norwegian part of the Sveconorwegian orogen is very similar, $1.73 \pm 1.45 \mu \mathrm{W} \mathrm{m}^{-3}$ (Slagstad 2008). This is notable, because any substantial difference would raise concerns that values from these two national data sets are not comparable due to methodological or sampling bias. In the Norwegian Caledonides, 167 determinations from intrusive rocks have yielded a value of $1.73 \pm 1.45 \mu \mathrm{W} \mathrm{m}^{-3}$ and 561 determinations from metasedimentary and metamafic rocks a value of $1.40 \pm 1.39 \mu \mathrm{W} \mathrm{m}^{-3}$ (Slagstad 2008), smaller than in Sweden but within the standard deviation of the very small Swedish data set. From Finnish Caledonides, 16 determinations are available (Rasilainen et al. 2007) and these show heat production even more lower than that in Sweden, from 0.24 to $1.16 \mu \mathrm{W} \mathrm{m}^{-3}$ depending on subunit (Veikkolainen \& Kukkonen 2019). The small number and uneven spatial distribution of Swedish and Finnish samples is the most likely explanation for difference. Comparison of Fig. 5 in our paper and the Finnish geologically averaged heat production (Fig. 15 in Veikkolainen \& Kukkonen 2019) shows that in the northern Svecokarelian (Svecofennian) parts of both countries, heat production values remain more or less similar across the country border, thus proving that also Swedish and Finnish data sets can be compared.

For studying the relation between heat production and rock density, we applied 23127 value pairs, for each of which a density value had been determined directly, not as a mean of the respective rock unit. We separated granitoids $(N=14124)$ and another data set of sediments and metasediments $(N=1642)$ from the rest of data $(N=7361)$. For calculation of heat production, we used the measured density of the rock instead of the mean density of the rock unit, unlike in other parts of our analysis. Unmetamorphosed granites $(N=7218)$ formed more than half of our granitoid group. However, a part of rocks $(N=1971)$ in granitoid group are likely to be somewhat metamorphosed. These include gneiss granites $(N=1185)$, gneiss granitoids (generic; $N=162)$, gneiss granodiorites $(N=473)$ and gneiss tonalites $(N=151)$. Fig. 6 shows that the granitoid group has a peak of high heat production values (over $5 \mu \mathrm{W} \mathrm{m}^{-3}$ ) in the density range of $2550-2700 \mathrm{~kg} \mathrm{~m}^{-3}$, but in the sedimentary and metasedimentary group, no such peak is visible but the distribution is relatively flat. In the group of other rocks, a slight decrease of heat production as a function of density is apparent. This is not unexpected, since pegmatites $(N=175)$ do not belong to granitoid group but may have high heat production as well. Otherwise the high heat production values in this group are represented by a variety of rocks such as mylonites, paragneisses, rhyolites and even volcanic rocks.

In Sweden, heat production values over $5 \mu \mathrm{W} \mathrm{m}^{-3}$ are almost exclusive to rocks with density less than $2800 \mathrm{~kg} \mathrm{~m}^{-3}$, typical of felsic lithology. Altogether 20 samples had heat production over 25 $\mu \mathrm{W} \mathrm{m}^{-3}$, and for clarity, these are not shown in plots. Also, one sample has a density over $3600 \mathrm{~kg} \mathrm{~m}^{-3}$ and was left out of plots. Mean density and its standard deviation in granitoid group was $2665.5 \pm 67.2 \mathrm{~kg} \mathrm{~m}^{-3}$, in sedimentary group $2702.5 \pm 76.8 \mathrm{~kg} \mathrm{~m}^{-3}$, and in the group of other rocks $2765.1 \pm 147.7 \mathrm{~kg} \mathrm{~m}^{-3}$. Mean heat production rates in these groups, as determined using directly measured rock densities, were $2.64 \pm 1.96,1.88 \pm 1.83$ and $1.88 \pm 1.86$ $\mu \mathrm{W} \mathrm{m}{ }^{-3}$. Similar heat production rates in two groups is merely a coincidence resulting from the fact that the third group, i.e. other rocks, has a very wide range of lithologies from rhyolites to basalts. In Fig. 6, linear fits are visible just to show the general trend, as it is not possible to predict heat production from rock density. This conclusion is similar to that drawn by Slagstad (2008) in the case of Norwegian data, and Veikkolainen \& Kukkonen (2019) in the case of Finnish data. Not surprisingly, histograms of radiogenic element concentrations appear skewed to the right in case of $\mathrm{C}_{\mathrm{U}}$ and $\mathrm{C}_{\mathrm{Th}}$, and to the left in case of $\mathrm{C}_{\mathrm{K}}$, as seen in Fig. 7. Globally, heat production increases as a function of felsic and alkali content in igneous rocks, both in plutonic and volcanic ones (Hasterok \& Webb 2017), and Sweden makes no exception to the rule.

Ternary diagram of normalized heat production is shown in Fig. 8. We left out all point data with heat production of exactly $0 \mu \mathrm{W} \mathrm{m}^{-3}$, meaning that 39364 data entries remained. Average proportions of heat production from $\mathrm{U}$, Th and $\mathrm{K}$ appeared to be $42.4,40.8$ and 16.8 per cent. The values of $U$ and $T h$ are slightly different from their Finnish counterparts of 36.7 and 47.0 per cent, while the value of $K$ is almost same as the Finnish result 16.3 per cent (Veikkolainen \& Kukkonen 2019). The variation of K content appears to be smaller between different geological units, and the general role of $\mathrm{K}$ in heat production is small. The proportion of $\mathrm{U}$, however, appears to be highly variable, as it is in Finnish data, and this emphasizes the importance of studying $\mathrm{Th} / \mathrm{U}$ ratio rather than $\mathrm{K} / \mathrm{Th}$ or $\mathrm{K} / \mathrm{U}$ ratios which have been recently investigated globally (Hasterok et al. 2018). Contours indicate that the majority of Swedish heat production values fall within a narrow range of $U$, Th and $K$ values, reminiscent of what has been observed in Finland and also globally. Given the small proportion of Phanerozoic rocks in Finnish and Swedish data compilations, it may be even possible to generalize this result to various other areas dominated by Precambrian lithology.

\section{DISCUSSION}

Our observation that heat production in Sweden is larger than in Finland is essential for further understanding of lithospheric structure in Fennoscandian shield and adjacent units. The crustal differentiation index (Perry et al. 2006) is therefore also larger in Sweden than in Finland, particularly if the same Moho heat flow constraint of $12 \pm 3 \mathrm{~mW} \mathrm{~m}^{-2}$ (Kukkonen \& Peltonen 1999; Kukkonen \& 


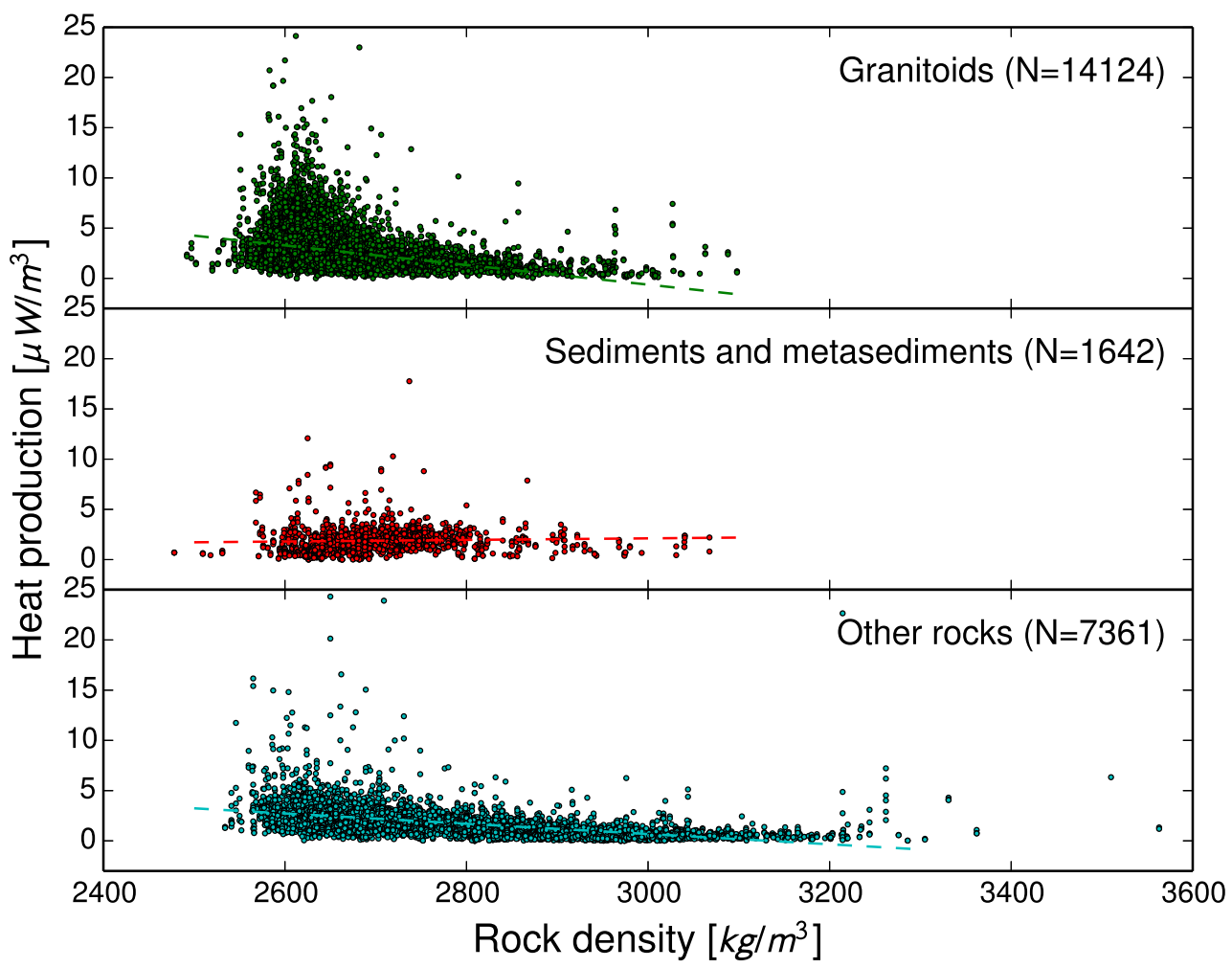

Figure 6. Heat production by rock density in three groups of rocks with directly measured densities. Dashed lines show linear fits to data points, yet these only indicate the general trend. Data $(C)$ SGU.
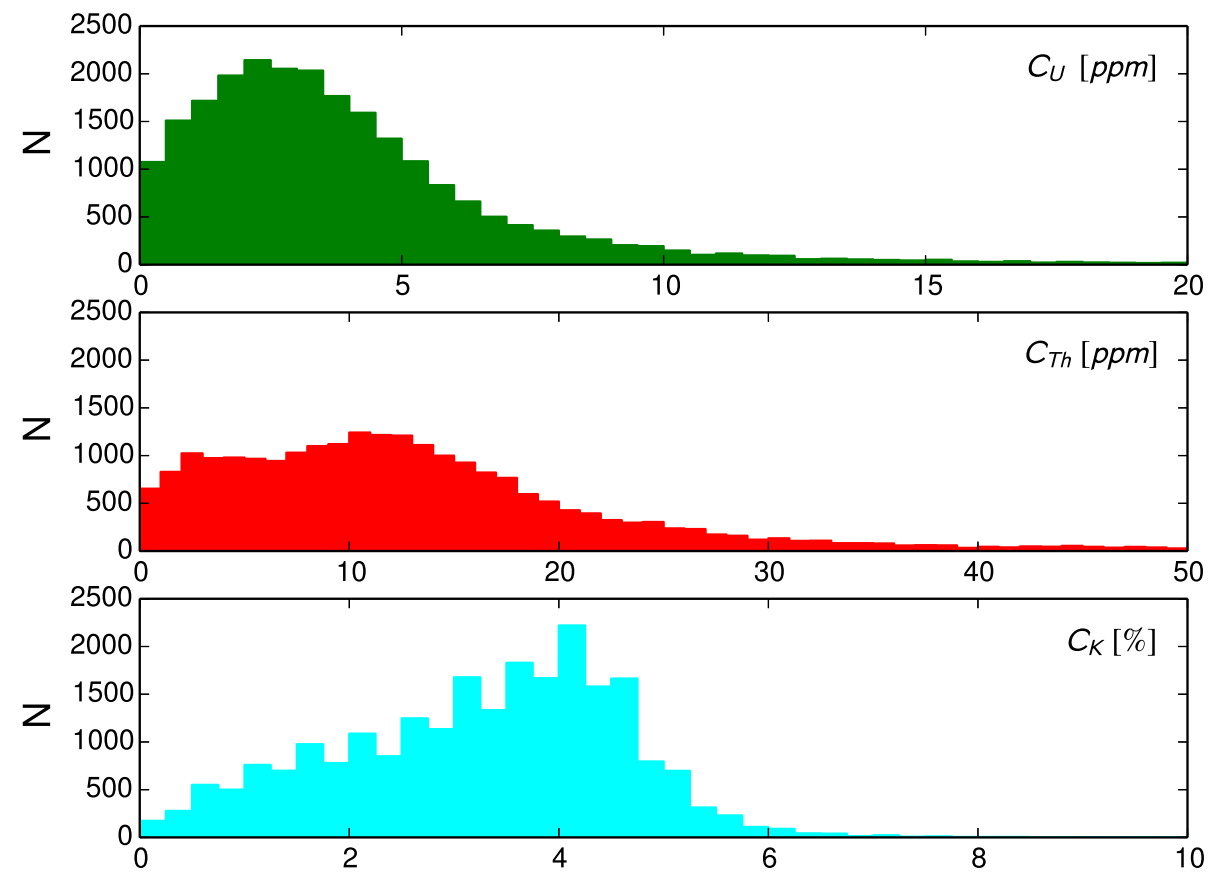

Figure 7. Histograms of radiogenic element concentrations for rocks with directly measured densities $(N=23127)$. Bin size is 0.5 ppm for $\mathrm{C}_{\mathrm{U}}, 1 \mathrm{ppm}$ for $\mathrm{C}_{\mathrm{Th}}$ and 0.25 per cent for $\mathrm{C}_{\mathrm{K}}$. For clarity, large outlier values with $\mathrm{C}_{\mathrm{U}}>20 \mathrm{ppm}, \mathrm{C}_{\mathrm{Th}}>50 \mathrm{ppm}$ and $\mathrm{C}_{\mathrm{K}}>10$ per cent are not shown. Data $\odot \mathrm{SGU}$.

Lahtinen 2001; Kukkonen et al. 2003) is valid for the entire shield. Despite variations in Moho depth in the shield area (Grad \& Tiira 2012; Grad et al. 2014; Bagherbandi et al. 2015), Moho heat flow outside the Caledonides should be nearly similar throughout the shield, given the absence of elevation contrasts. However, the lack of heat production constraints in several Swedish areas with high heat flow, the absence of heat flow determinations in areas of strongly enriched crust in northern Sweden, and the poor knowledge of the thickness of the upper crustal heat producing layer impair our ability to draw detailed conclusions on heat production. The problem of 


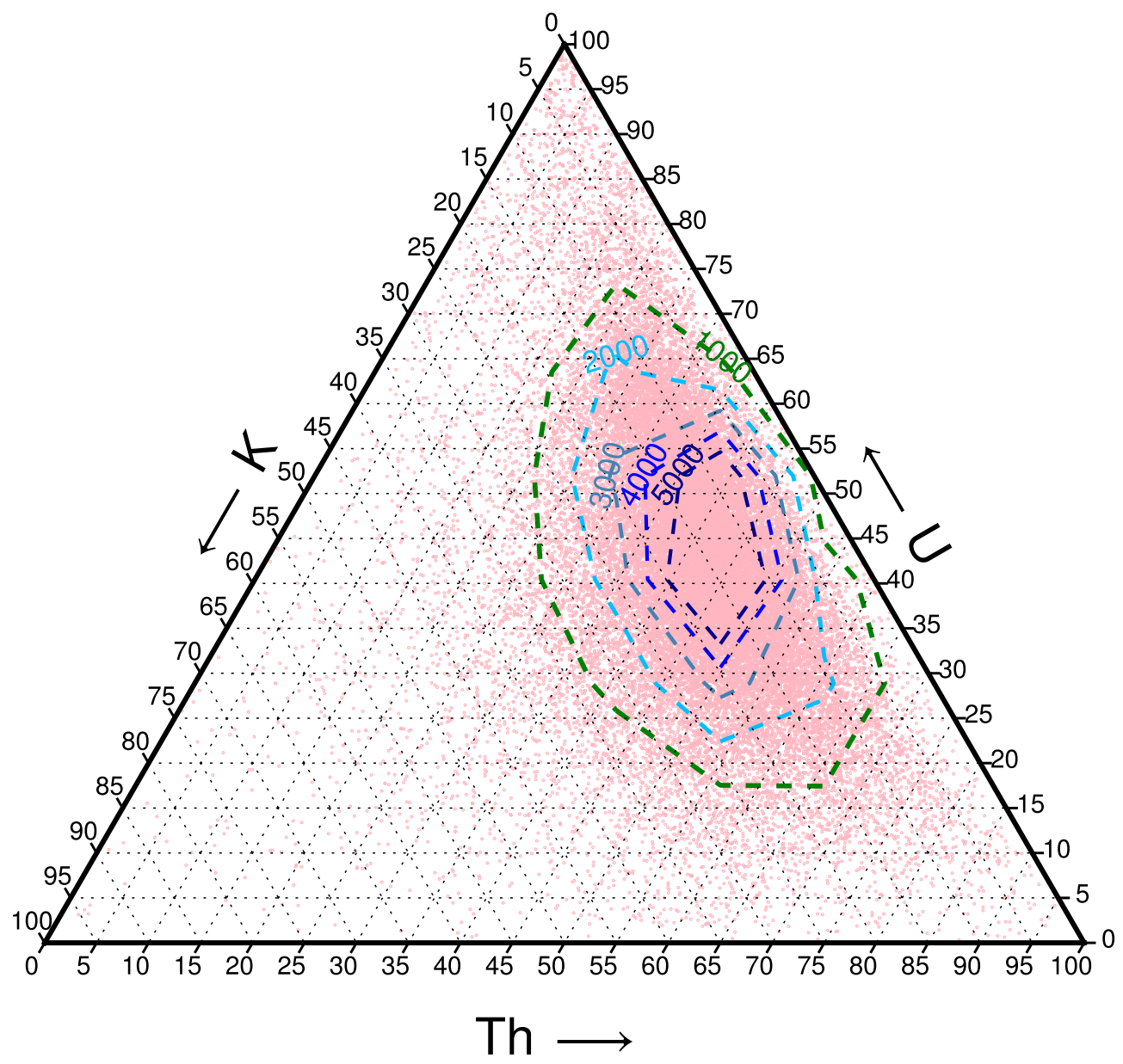

Figure 8. Ternary plot of proportions of $\mathrm{U}$, Th and $\mathrm{K}$ in raw Swedish heat production data $(N=39364)$. No data with zero heat production are included. Density contours for 1000, 2000, 3000, 4000 and 5000 data points are also shown. Data $\odot$ SGU.

spatial gaps in the Swedish data remains until a new sampling campaign is launched, although inversion of other geophysical data may give clues about heat production in areas without outcrops (Hokstad et al. 2017). Thus far, generalization is needed, and it has been done also in other countries with certain economically interesting areas of high heat production. For example, in Australia more than 80 per cent of radiogenic element concentration data of Proterozoic rocks have been obtained from the North Australian Craton. Large variations of heat production in Precambrian areas are not exceptional, but have been observed e.g. in Australia (McLaren \& Powell 2014) and in India (Menon et al. 2003; Singh et al. 2014) as well.

In determination of heat production, airborne gamma ray surveys are often preferred over laboratory measurements due to the better spatial coverage of measurements obtained from flights. For example, the heat flow map of Näslund et al. (2005) over Finland and Sweden is based on airborne gamma ray data from Sweden, geochemical data from 1054 Finnish glacial till measurements (Kukkonen 1989) and linear Q-A relationship (Birch et al. 1968). The resulting mean heat flow value $49 \mathrm{~mW} \mathrm{~m}^{-2}$ obtained for two countries (Näslund et al. 2005) is similar to that obtained by Veikkolainen et al. (2017). Because heat flow in Figs 1 and 2 of Näslund et al. (2005) was directly proportional to heat production, a qualitative comparison between our heat production map and maps of Näslund et al. (2005) is possible. Most northern Swedish areas with high heat production (Figs 6 and 8 in our paper) are barely visible as areas with high heat flow in maps of Näslund et al. (2005) but conversely, in the southeastern part, heat flow maps show high values in large areas unlike our heat production maps do. The problems of interpreting airborne radiometric data were discussed recently by Phaneuf \& Mareschal (2014), who observed that the mean heat production determined from airborne data $\left(0.8 \pm 0.6 \mu \mathrm{W} \mathrm{m}^{-3}\right)$ of Sudbury region, Canada, was significantly lower than that determined from laboratory measurements $\left(2.9 \pm 2.5 \mu \mathrm{W} \mathrm{m}^{-3}\right)$ from rocks of the same area. Even though Näslund et al. (2005) only included airborne measurements from exposed bedrock, these cover only a small fraction of the measurement area even in glaciated areas such as Sweden and Finland, and therefore the problem of uneven sampling remains, although airborne surveys can conveniently cover large areas.

\section{CONCLUSIONS}

Our analyses of heat production from outcrop samples in the SGU lithogeochemical database were based on three methods: (1) calculation from point data after averaging values at exactly same SWEREF 99 TM coordinates; (2) using regular grid with $5 \mathrm{~km}$ bin size and (3) calculating values within actual geological units. Regardless of method, mean heat production stays within the range of 2.3. . $2.6 \mu \mathrm{W} \mathrm{m} \mathrm{m}^{-3}$, but the value obtained by averaging by geological units $\left(2.4 \pm 1.7 \mu \mathrm{W} \mathrm{m}^{-3}\right)$ is probably the most useful, especially in cases where comparison with Finnish (Veikkolainen \& Kukkonen 
2019) and Norwegian (Slagstad 2018) heat production maps needs to be done. Despite spatial gaps in point data, most tectonic units and subunits are adequately covered, and data are coherent with those obtained from neighbouring countries.

The outcome of this study confirms previous assumptions of higher heat production and surface heat flow in Sweden compared to those of Finland (Näslund et al. 2005). Both Finnish (Veikkolainen \& Kukkonen 2019) and Swedish heat production studies are based on analyses of radiogenic element concentrations from outcrop samples from largest national data compilations available. The vast majority of heat production data from both countries originates from Precambrian rocks, and leaving the small Phanerozoic part out of analysis makes no obvious difference. Following the tradition of till geochemical analyses of two or more Fennoscandian countries (Gustavsson et al. 1994; Edén \& Björklund 1995), it may be feasible to combine Swedish, Finnish and also Norwegian heat production data in a common database after a thorough comparison of analytical procedures used to obtain results in national databases. The presence of bedrock outcrops and the absence of platform cover in the majority of land area in these countries makes it convenient to generalize measurement results from surface rocks to greater depths in order to study the composition of the lithosphere using mixtures of rock types at different depths, although this requires additional seismic evidence on the layer structure of the lithosphere (Kuusisto et al. 2006).

\section{SUPPORTING INFORMATION}

Supplementary data are available at GJI online.

Appendices: Unaveraged heat production data at SWEREF 99 TM coordinates are tabulated in Appendix A. Heat production plots based on two binning options described in the text are shown in Appendix B. Swedish bedrock units with exceptionally high heat production (over $5 \mu \mathrm{W} \mathrm{m}^{-3}$ ) are listed and described in Appendix C. Heat flow data are tabulated in Appendix D.

Please note: Oxford University Press are not responsible for the content or functionality of any supporting materials supplied by the authors. Any queries (other than missing material) should be directed to the corresponding author for the paper.

\section{ACKNOWLEDGEMENTS}

We are grateful to Johan Söderman (SGU; Geological Survey of Sweden) for providing the lithogeochemical data essential for analysis, and granting a licence to use the data for non-commercial research purposes. The work of Toni Veikkolainen received funding from the Jenny and Antti Wihuri Foundation, Finland. This paper was improved by reviews of Derrick Hasterok and Trond Slagstad.

\section{REFERENCES}

Andersson, M., Carlsson, M., Ladenberger, A., Morris, G., Sadeghi, M. \& Snöälv, J., 2014. Geochemical Atlas of Sweden, pp. 208, Geological Survey of Sweden.

Andersson, U. \& Förster, H.-J., 2003. Mineralogical-geochemical evolution and the formation of REE fluorocarbonates in a silicic rapakivi granite system: the Rödö Complex, central Sweden, J. Czech Geol. Soc., 48, $13-15$.

Bagherbandi, M., Sjöberg, L.E., Tenzer, R. \& Abdehdary, M., 2015. A new Fennoscandian crustal thickness model based on CRUST1.0 and a gravimetric-isostatic approach, Earth-Sci. Rev., 145, 132-145.
Balling, N., 2013. The Lithosphere Beneath Northern Europe: Structure and Evolution Over Three Billion Years. Contributions from Geophysical Studies, pp. 201, PhD thesis, Aarhus University, Aarhus, Denmark.

Bingen, B., Nordgulen, Ø. \& Viola, G., 2008. A four-phase model for the Sveconorwegian orogeny, SW Scandinavia, Norw. J. Geol., 88, 43-72.

Birch, F., Roy, R.F. \& Decker, E.R., 1968. Heat flow and thermal history in New York and New Englandin Studies of Appalachian Geology: Northern and Maritime, pp. 473-451, eds Zen, E., White, W., Hadley, J.B. \& Thompson, J.B., Interscience.

Edén, P. \& Björklund, A., 1995. Geochemistry of till in Fennoscandia from ultra-low density sampling, J. Geochem. Expl., 52, 285-302.

Eriksson, K.G. \& Malmqvist, D., 1979. A review of the past and present investigations of heat flow in Sweden, eds Cermak, V. \& Rybach, L., Terrestrial Heat Flow in Europe, Springer, pp. 267-277.

Fornberg, B, Driscoll, T.A., Wright, G. \& Charles, R., 2002. Observations on the behavior of radial basis function approximations near boundaries, Comput. Math. Appl., 43, 473-490.

Grad, M. \& Tiira, T., 2012. Moho depth of the European Plate from teleseismic receiver functions, J. Seismol., 16, 95-105.

Grad, M., Tiira, T., Olsson, S. \& Komminaho, K., 2014. Seismic lithosphereasthenosphere boundary beneath the Baltic Shield, GFF, 136, 581-598.

Gustavsson, N., Lampio, E., Nilsson, B., Norblad, G., Ros, F. \& Salminen, R., 1994. Geochemical maps of Finland and Sweden J. Geochem. Expl., 51, 143-160.

Hannington, M.D., Kjarsgaard, I.M., Galley, A.G. \& Taylor, B., 2003. Mineral-chemical studies of metamorphosed hydrothermal alteration in the Kristineberg volcanogenic massive sulfide district, Sweden, Miner. Deposita, 38, 423-442.

Hasterok, D. \& Chapman, D.S., 2011. Heat production and geotherms for the continental lithosphere, Earth planet. Sci. Lett., 307, 59-70.

Hasterok, D., Gard, M. \& Webb, J., 2018. On the radiogenic heat production of metamorphic, igneous, and sedimentary rocks, Geosci. Front., 9, $1777-$ 1794.

Hasterok, D. \& Webb, J., 2017. On the radiogenic heat production of igneous rocks, Geosci. Front., 8, 919-940.

Hokstad, K., Tašárová, Z.A., Clark, S.A., Kyrkjebø, R., Duffaut, K., Fichler, C. \& Wiik, T., 2017. Radiogenic heat production in the crust from inversion of gravity and magnetic data, Norw. J. Geol., 97, 191-204.

Huang, Y., Chubakov, V., Mantovani, F., Rudnick, R.L. \& McDonough, W.F., 2013. A reference Earth model for the heat-producing elements and associated geoneutrino flux, Geochem., Geophys., Geosyst., 14, 20032029.

Hurter, S. \& Hänel, R., 2002. Atlas of Geothermal Resources in Europe, pp. 92, Publication EUR 17811, European Commission.

Hyvönen, E., Turunen, P., Vanhanen, E., Arkimaa, H. \& Sutinen, R., 2005. Airborne gamma-ray surveys in Finland, Geol. Surv. Finland Spec. Paper, 39, 119-134.

Högdahl, K., Andersson, U.B. \& Eklund, O., eds., 2004. The Transscandinavian Igneous Belt (TIB) in Sweden: a review of its character and evalution, Geol. Surv. Finland Spec. Paper, 37, 123.

Johansson, $\AA ., 1990$. Age of the Önnestad syenite and some gneissic granites along the southern part of the Protogine Zone, Geol. Assoc. Canada Spec. Paper, 38, 131-148.

Johansson, Å., Bogdanova, S. \& Čečys, A., 2005. A revised geochronology for the Blekinge Province, southern Sweden, GFF, 128, 287-302.

Kock, P. \& Samuelsson, C., 2011. Comparison of airborne and terrestrial gamma spectrometry measurements - evaluation of three areas in southern Sweden, J. Environ. Radioact., 102, 605-613.

Kukkonen, I.T., 1989. Terrestrial heat flow and radiogenic heat production in Finland, the central Baltic Shield, Tectonophys., 164, 219-230.

Kukkonen, I.T. \& Jõeleht, A., 2003. Weichselian temperatures from geothermal heat flow data, J. geophys. Res.: Solid Earth, 108, 2163.

Kukkonen, I.T., Kinnunen, K. \& Peltonen, P., 2003. Mantle xenoliths and thick lithosphere in the Fennoscandian Shield, Phys. Chem. Earth, 28, 349-360.

Kukkonen, I.T. \& Lahtinen, R., 2001. Variation of radiogenic heat production rate in 2.8-1.8 Ga old rocks in the central Fennoscandian shield, Phys. Earth planet. Inter., 126, 279-294. 
Kukkonen, I.T. \& Peltonen, P., 1999. Xenolith-controlled geotherm for the central Fennoscandian Shield: implications for lithosphere-asthenosphere relations, Tectonophysics, 304, 301-315.

Kumpulainen, R.A., Mansfeld, J., Sundblad, K., Neymark, L. \& Bergman, T., 1996. Stratigraphy, age, and Sm-Nd isotope systematics of the country rocks to Zn-Pb sulfide deposits, Åmmeberg District, Sweden, Econ. Geol., 91, 1009-1021.

Kuusisto, M., Kukkonen, I.T., Heikkinen, P. \& Pesonen, L.J., 2006. Lithological interpretation of crustal composition in the Fennoscandian Shield with seismic velocity data, Tectonophysics, 420, 283-299.

Landström, O., Larson, S.-Å., Lind, G. \& Malmqvist, D., 1980. Geothermal investigations in the Bohus granite area in southwestern Sweden, Tectonophysics, 64 131-162.

Landström, O., Larson, S.A., Lind, G. \& Malmqvist, D., 1979. Värmeflod i berg. Geologiska Institutionen, Chalmers Tekniska Högskola, Publication $B, \mathbf{1 3 7}, 1-86$.

Lindén, A., Melin, O. \& Mellander, H., 1983. Regions with an anomalous heat production, Flygmätningsavdelingen, Sveriges Geologiska $\mathrm{AB}$.

Majorowicz, J. \& Wybraniec, S., 2010. New terrestrial heat flow map of Europe after regional paleoclimatic correction application, Int. J. Earth Sci., 100, 881-887.

Malmqvist, D., Larson, S.A., Landström, O. \& Lind, G., 1983. Heat flow and heat production from the Malingsbo granite, central Sweden, Bull. Geol. Inst. Univ. Uppsala, 9, 137-152.

Mansfeld, J., Beunk, F. \& Barling, J., 2005. 1.83-1.82 Ga formation of a juvenile volcanic arc-implications from $\mathrm{U}-\mathrm{Pb}$ and $\mathrm{Sm}-\mathrm{Nd}$ analyses of the Oskarshamn-Jönköping belt, southeastern Sweden, GFF, 127, 149157.

McLaren, S. \& Powell, R., 2014. Magmatism, orogeny and the origin of high-heat-producing granites in Australian Proterozoic terranes, J. Geol. Soc., 171, 149-152.

Menon, R., Kumar, P.S., Koti Reddy, G. \& Srinivasan, R., 2003. Radiogenic heat production of Late Archaean Bundelkhand granite and some Proterozoic gneisses and granitoids of central India, Current Sci., 85, 634-638.

Moakhar, M.O. \& Elming, S.-Å., 2000. A palaeomagnetic analysis of Rapakivi intrusions and related dykes in the Fennoscandian Shield, Phys. Chem. Earth Part A, 25, 489-494.

Näslund, J.-O., Jansson, P., Fastook, J.L., Johnson, J. \& Anderson, L., 2005. Detailed spatially distributed geothermal heat-flow data for modeling of basal temperatures and meltwater production beneath the Fennoscandian ice sheet, Ann. Glaciol., 40, 95-101.

Parasnis, D.S., 1982. Geothermal flow and phenomena in two Swedish localities north of the Arctic circle, Geophys. J. R. astr. Soc., 71, $545-554$.

Perry, H.K.C., Jaupart, C., Mareschal, J.-C. \& Bienfait, G., 2006. Crustal heat production in the Superior Province, Canadian Shield, and in North America inferred from heat flow data, J. geophys. Res.: Solid Earth, 111, B04401, doi:10.1029/2005JB003893.

Persson, A.I., 1999. Absolute (U-Pb) and relative age determinations of intrusive rocks in the Ragunda rapakivi complex, central Sweden, Precambrian Res., 95, 109-127.

Phaneuf, C. \& Mareschal, J.C., 2014. Estimating concentrations of heat producing elements in the crust near the Sudbury Neutrino Observatory, Ontario, Canada, Tectonophys, 622, 135-144.

Pinet, C. \& Jaupart, C., 1987. The vertical distribution of radiogenic heat production in the Precambrian crust of Norway and Sweden: Geothermal implications, Geophys. Res. Lett., 14, 260-263.
Piper, J.D.A., 1979. Palaeomagnetism of the Ragunda intrusion and dolerite dykes, Central Sweden, Geologiska Föreningens $i$ Stockholm Förhandlingar, 101, 139-148.

Rasilainen, K., Lahtinen, R. \& Bornhorst, T.J., 2007. The Rock Geochemical Database of Finland Manual, pp. 38, Geological Survey of Finland, Report of Investigation 164.

Roberts, N.M.W., Slagstad, T., Parrish, R.R., Norry, M.J., Marker, M. \& Horstwood, M.S.A., 2013. Sedimentary recycling in arc magmas: geochemical and U-Pb-Hf-O constraints on the Mesoproterozoic Suldal Arc, SW Norway, Contrib. Mineral. Petrol., 165, 507-523.

Rudnick, R.L. \& Gao, S., 2014. Composition of the Continental Crust, in Treatise on Geochemistry, pp. 1-51, ed. Rudnick, R.L., Elsevier.

Rybach, L., 1973. Wärmeproduktionsbestimmungen an Gesteinen der Schweizer Alpen, Vol. 51, pp. 43, Beiträge zur Geologie der Schweiz: Geotechnische Serie.

Sadeghi, M., Morris, G.A., Carranza, E.J.M., Ladenberger, A. \& Andersson, M., 2013. Rare earth element distribution and mineralization in Sweden: an application of principal component analysis to FOREGS soil geochemistry, J. Geochem. Expl., 133, 160-175.

Singh, H., Kumar, Y., Chandrasekharam, D, Gurav, T. \& Singh, B., 2014. High-heat-producing granites of East Dharwar Craton around Gugi, Karnataka, and their possible influence on the evolution of Rajapur thermal springs, Deccan Volcanic Province, India, Geother. Ener., 2, 2.

Slagstad, T., 2008. Radiogenic heat production of Archaean to Permian geological provinces in Norway, Norw. J. Geol., 88, 149-166.

Slagstad, T., Balling, N., Elvebakk, H., Midttømme, K., Olesen, O., Olsen, L. \& Pascal, C., 2009. Heat-flow measurements in Late Palaeoproterozoic to Permian geological provinces in south and central Norway and a new heat-flow map of Fennoscandia and the Norwegian-Greenland Sea, Tectonophysics, 473, 341-361.

Slagstad, T. et al., 2018. Magma-driven, high-grade metamorphism in the Sveconorwegian Province, SW Norway during the terminal stages of Fennoscandian Shield evolution, Geosphere, 14, 861-882.

Sopher, D., Erlström, M., Bell, N. \& Juhlin, C., 2016. The structure and stratigraphy of the sedimentary succession in the Swedish sector of the Baltic Basin: New insights from vintage 2D marine seismic data, Tectonophysics, 676, 90-111.

Sundberg, J., Back, P.E., Ländell, M. \& Sundberg, A., 2009. Modelling of temperature in deep boreholes and evaluation of geothermal heat flow at Forsmark and Laxemar, pp. 96, Swedish Nuclear Fuel and Waste Management Company, Technical Report TR-09-14.

Sundberg, J., Näslund, J.-O., Liljedahl, L.C., Wrafter, J., O-Regan, M., Jakobsson, M., Preto, P. \& Larson, S.Å., 2016. Thermal Data for Paleoclimate Calculations from Boreholes at Lake Vättern, pp. 159, Swedish Nuclear Fuel and Waste Management Company, Report $P$-16-03.

Veikkolainen, T. \& Kukkonen, I.T., 2019. Highly varying radiogenic heat production in Finland, Fennoscandian Shield, Tectonophys., 750, 93-116.

Veikkolainen, T., Kukkonen, I.T. \& Tiira, T., 2017. Heat flow, seismic cutoff depth and thermal modeling of the Fennoscandian Shield, Geophys. J. Int., 211, 1414-1427.

Wilkinson, B.H., McElroy, B.J., Kesler, S.E., Peters, S.E. \& Rothman, E.D., 2009. Global geologic maps are tectonic speedometers-rates of rock cycling from area-age frequencies, Geol. Soc. Am. Bull., 121, 760-779.

Wilson, M.R. \& Åkerblom, G.V., 1982. Geological setting and geochemistry of uranium-rich granites in the Proterozoic of Sweden, Mineral. Mag., 46, 233-245.

Čermak, V., Balling, N., Kukkonen, I. \& Zui, V.I., 1993. Heat-flow in the Baltic Shield: results of the lithospheric geothermal modeling, Prec. Res., 64, 53-65. 